\title{
FILSAFAT PENDIDIKAN ISLAM:
}

\section{Tinjauan Antroposentris Tentang Konsep Pendidikan Manusia}

\author{
Muhammad \\ Sekolah Tinggi Ilmu Keguruan (STKIP) Taman Siswa Bima \\ Email: muhammadqu@gmail.com
}

\begin{abstract}
Abstrak:
Kedudukan manusia dalam proses pendidikan senantiasa diperbincangkan dalam perspekstif akademik, mengingat manusia merupakan aktor utama selaku subjek dan objek pendidikan. Salah satu pokok persoalan yang selalu didiskusikan tentang manusia dalam pelaksanaan pendidikan adalah eksistensi manusia yang dapat dididik dan harus mendidik. Dalam al-Qur'an manusia digeneralkan dengan kosa kata al-insan berasal dari kata anasa yang arinya melihat, dan banyak dijelaskan dalam al-Qur'an. Kata insan yang bentuk jamaknya al-nas dasar kata anasa, yang berarti melihat, mengetahui dan meminta izin. Sehingga muatannya mengandung petunjuk adanya keterkaitan antara manusia dengan kemampuan penalaran, yakni manusia dapat mengambil pelajaran dari apa yang dilihatnya, ia dapat pula mengetahui apa yang benar dan apa yang salah, dan terdorong meminta izin untuk menggunakan sesuatu yang bukan miliknya. Pengertian tersebut, menunjukan adanya potensi manusia untuk dididik dan mendidik pada diri manusia. Sehingga memberikan gambaran bahwa manusia memiliki kemampuan yang tinggi untuk beradaptasi dengan perubahan yang terjadi di lingkungannya, baik perubahan sosial maupun perubahan alamiah sebagai proses pendidikan dalam diri seorang manusia.
\end{abstract}

Kata Kunci: Manusia, Potensi, Pendidikan.

\section{Pendahuluan}

endidikan merupakan serangkaian aktivitas yang tidak terpisahkan dalam poros kehidupan manusia. Proses pendidikan akan terus terlaksana 1 sepanjang ada kehidupan manusia di dunia ini, dalam artian bahwa pendidikan akan senantiasa berkembang yang bersamaan dengan proses perkembangan hidup dan kehidupan manusia itu sendiri. ${ }^{1}$ Dilihat dari aspek maknanya, pendidikan diartikan sebagai pola pembentukan kecakapan-kecakapan intelektual maupun emosional ke arah alam dan sesama manusia. ${ }^{2}$ Dalam konteks Islam pendidikan juga diistilahkan sebagai usaha orang dewasa muslim yang bertakwa secara sadar untuk mengarahkan dan membimbing pertumbuhan serta perkembangan fitrah (kemampuan dasar) peserta didik melalui ajaran Islam ke arah titik maksimal pertumbuhan dan perkembangannya. ${ }^{3}$ Secara substantif

${ }^{1}$ Muzayyin Arifin, Filsafat Pendidikan Islam (Cet. IV; Jakarta: PT Bumi Aksara, 2008),

${ }^{2}$ Hasbullah, Dasar-Dasar Pendidikan (Cet. X; Jakarta: PT Rajgrafindo Persada, 2012), 2.

${ }^{3}$ Arifin, Ilmu Pendidikan Islam (Cet. V; Jakarta: PT Bumi Aksara, 2011), 22. 
manusia memiliki peranan yang amat besar terkait pelaksanaan pendidikan karena pada hakikatnya manusia adalah objek sekaligus subjek pendidikan terlebih lagi di dalam konsep Islam ditegaskan bahwa pendidikan hanya dikhususkan untuk manusia semata. ${ }^{4}$

Meski demikian penelahaan perihal hakikat manusia sangatlah sukar dieksploratif secara utuh, akan tetapi eksistensi manusia selalu menarik untuk dikaji dan diselidiki, baik dari sisi tingkah lakunya maupun adat istiadatnya melalui pengembangan-pengembangan pendidikan. Bahkan para ahli sepakat bahwa teori dalam praktik pendidikan, khususnya pendidikan Islam sangatlah dipengaruhi oleh pandangan tentang fitrah manusia. ${ }^{5}$ Lebih lanjut, Menurut Ahmad Tafsir merujuk pendapat Marimba mengemukakan bahwa tujuan pendidikan Islam adalah terbentuknya orang-orang berkepribadian muslim. Pandangan senada juga diungkap oleh Abdul Fath Jalal dalam buku yang sama mengungkapkan bahwa tujuan umum pendidikan Islam yakni terwujudnya manusia sebagai hamba Allah. ${ }^{6}$ Ia menegaskan bahwa tujuan tersebut dipreoritaskan untuk seluruh manusia, agar menjadi manusia yang menghambakan diri kepada Allah swt. Penghambaan diri yang dimaksud ialah beribadah kepada Allah swt, sebagaimana firman-Nya dalam QS Az-Zariyat/51: 56.

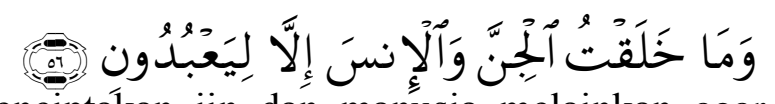

Terjemahanya: "Dan Aku tidak menciptakan jin dan manusia melainkan agar mereka beribadah kepada-Ku". 7

Dalam hemat penuis, uraian di atas menekankan beberapa poin penting yang dapat dipahami. Pertama, memberikan gambaran secara historiografi bahwa perkembangan pendidikan pada dasarnya sejalan dengan adanya manusia di dunia ini, mengingat manusia adalah aktor utama yang bertindak sebagai objek maupun subjek dalam proses pendidikan. Kedua, menjelaskan bahwa konsep pendidikan, khususnya pendidikan Islam secara makna dapat disederhanakan sebagai upaya pembentukan tingkah laku manusia berdasarkan nilai-nilai ajaran Islam.

Berbicara tentang masalah pendidikan Islam tidak hanya terbatas pada persoalan makna pendidikan ataupun tujuan pendidikan Islam sebagai wahana pengembangan kepribadian, dengan penekanan nilai-nilai ajaran Islam. Akan tetapi salah satu aspek yang paling pokok untuk diketahui yakni sejauhmana peran penting pendidikan Islam dalam pembentukan sikap dan tingkah laku manusia

\footnotetext{
2009), 19.

${ }^{4}$ Kemas Badaruddin, Filsafat Pendidikan Islam (Cet. II; Yogyakarta: Pustaka Pelajar,

${ }^{5}$ Lihat Kemas Badaruddin, Filsafat Pendidikan Islam, h. 19.

${ }^{6}$ Ahmad Tafsir, Ilmu Pendidikan Dalam Perspekstif Islam (Cet. IX; Jakarta: Remaja Rosdakarya, 2010), 46.

${ }^{7}$ Departemen Agma RI, al-Qur'an dan Terjemahannya (Jakata: PT Sygma Examedia Arkanleema, 2009), 523.
} 
selaku objek kajian dalam pengembangan pendidikan. Berangkat dari maksud tersebut, penulis berusaha untuk menguraikan gambaran secara teoretis yang berkenaan dengan topik bahasan tentang filsafat pendidikan: sebuah. Besar harapan pembahasan makalah ini, dapat memberikan sumbangsi pengetahuan, terkhusus bagi penulis dan para praktisi pendidikan agar senantiasa berpikir inovatif dalam menyelenggarakan proses pendidikan.

\section{Manusia Memilki Fitrah/Potensi}

Pengkajian tentang esensi manusia bukanlah hal yang terdengar asing dalam konteks kekinian. Manusia merupakan pelaku sejarah dalam pembentukan peradaban di dunia ini. Selain itu, manusia adalah golongan makhluk yang diciptakan Allah swt dan memenuhi tingkat kesempurnaan bila dibandingkan dengan makhluk-makhluk lainnya. Salah satu aspek yang menjadi pembeda sekaligus menjadikan pribadi manusia sebagai makhluk superior dibandingkan makhluk lainnya, yakni manusia memiliki fitrah/potensi. Dilihat dari segi kebahasaan dalam Kamus Besar Bahasa Indonesia kata fitrah diartikan sebagai sifat asal, kesucian, bakat dan pembawaaan. ${ }^{8}$ Definisi serupa juga dijelaskan dalam Kamus Ilmiah Populer bahwa fitrah/potensi diartikan sebagai suatu kesanggupan, kemampuan, daya, maupun kefungsian. ${ }^{9}$

Dari sudut pandang istillah Abd. Rachman Assegaf berpendapat bahwa fitrah merupakan potensi yang dimiliki manusia untuk menerima agama, iman dan tauhid serta perilaku suci. ${ }^{10}$ Dalam pertumbuhannya, manusia sendirilah yang harus berupaya mengarahkan fitrah tersebut melalui iman atau tauhid melalui pendidikan, pergaulan dan lingkugan yang kondusif. Bila faktor tersebut tidak memiliki sumbangsi atau gagal dalam menumbuhkembangkan fitrah manusia, maka dapat dikatakan fitrah tersebut dalam keadaan tertutup, meskipun dapat dibuka kembali oleh faktor yang sama sebagai pendukungnya. ${ }^{11}$

Konsep fitrah tidaklah identik dengan teori tabula rasa, sama seperti halnya pandangan Islam tentang manusia tidaklah identik dengan aliran dualisme maupun convergency, sebab konsep teori tabula rasa sebagaimana yang diungkap Jhon locke, memandang manusia itu putih bersih, ibarat kertas yang belum dicoret. Sehingga intinya teori tabula rasa memandang manusia terlahir dalam keadaan pasif. Sebaliknya fitrah terdapat potensi yang terbawa oleh manusia,

\footnotetext{
${ }^{8}$ Departemen Pendidikan Nasional, Kamus Besar Bahasa Indonesia, Edisi IV (Cet. I; Jakarta: Gramedia Pustaka Utama, 2008), 393.

${ }^{9}$ Pius A. Partanto, Kamus Ilmiah Populer (Cet. I; Surabaya: Arkola, 2001), 627.

${ }^{10}$ Abd. Rachman Assegaf, Filsafat Pendidikan Islam (Cet. II; Jakarta: PT Rajagrafindo persada, 2011), 46.

${ }^{11}$ Lihat Abd. Rachman Assegaf, Filsafat Pendidikan Islam....,46.
} 
yakni daya dan kekuatan untuk menerima agama atau tauhid. Bedanya dengan teori tabula rasa, potensi lebih bersifat dinamis. ${ }^{12}$

Dalam perkembangannya lingkungan dan pendidikan merupakan faktor yang dapat menyebabkan bertambahnya atau berkurangnya potensi/fitrah manusia. Kondisi ini dikarenakan kedua faktor tersebut merupakan faktor yang dapat mempengaruhi tingkah laku manusia. Bahkan dalam Islam Nabi Muhammad saw, bersabda:

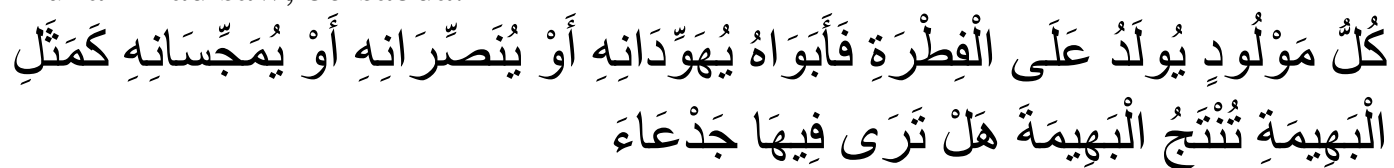

Artinya : "Setiap anak dilahirkan dalam keadaan suci, maka orang tuanyalah yang dapat menjadikanya yahudi, nasrani atau majusi". ${ }^{13}$

Uraian hadis di atas, menurut hemat penulis dalam kontennya tersirat makna bahwa lingkungan yang disimboliskan pada figur orang tua mempunyai pengaruh terkait perkembangan fitrah seorang anak terutama yang berkaitan dengan konsep penerimaan nilai-nilai keimanan kepada Tuhan-Nya. Menegaskan pandangan tersebut, fitrah/potensi yang dimiliki manusia, dalam Islam dijelaskan dalam al-Qur'an dengan menekankan dua kata kunci untuk memahami manusia secara komperehensif, yakni al-insan dan al-basyar. ${ }^{14}$

Kata insan yang bentuk jamaknya al-nas dasar kata anasa, yang berarti melihat, mengetahui dan meminta izin. Sehingga muatannya mengandung petunjuk adanya keterkaitan antara manusia dengan kemampuan penalaran, yakni manusia dapat mengambil pelajaran dari apa yang dilihatnya, ia dapat pula mengetahui apa yang benar dan apa yang salah, dan terdorong meminta izin untuk menggunakan sesuatu yang bukan miliknya. Pengertian tersebut, menunjukan adanya potensi manusia mendidik pada diri manusia. ${ }^{15}$ Sehingga memberikan gambaran bahwa manusia memiliki kemampuan yang tinggi untuk beradaptasi dengan perubahan yang terjadi di lingkungannya, baik perubahan sosial maupun perubahan alamiah. ${ }^{16}$

Sedangkan kata basyar, cenderung diasumsikan untuk menyebutkan semua makhluk, baik laki-laki ataupun perempuan, baik individu atau kolektif. Basyar berasal dari jamak kata basyarah yang artinya permukaan kulit kepala, wajah, dan tubuh yang menjadi tempat tumbuhnya rambut. Pemakaian kata

\footnotetext{
${ }^{12}$ Lihat Abd. Rachman Assegaf, Filsafat Pendidikan Islam ....,47.

${ }^{13}$ Abdul Majid Khon, Hadis Tarbawi Hadis-Hadis Pendidikan (Cet. I; Jakarta: Kencana Prenada Media Group, 2012), 235.

${ }^{14}$ Nasir A. Baki, Filsafat Pendidikan Islam (Cet. I; Makassar: Alauddin University Press, 2013), 64 .

${ }^{15}$ Lihat Nasir A. Baki, Filsafat Pendidikan Islam ...,65.

${ }^{16}$ Lihat Nasir A. Baki, Filsafat Pendidikan Islam...,65.
} 
basyar yang tertuang dalam al-Qur'an, secara umum menjelaskan sisi pengertian terkait anak Adam yang biasa makan dan berjalan-jalan di pasar-pasar dan di dalam pasar mereka saling bertemu atas dasar persamaan. Sehingga kata basyar mengacu kepada manusia berdasarkan aspek lahiriyahnya atau lebih mendeskripsikan makna manusia yang dari bentuk fisiologis. ${ }^{17}$ Di dalam fitrah, terdapat beberapa komponen psikologis yang saling memperkokoh dalam proses perkembangannya menuju arah kapasitas optimal. Komponen fitrah tersebut, meliputi: potensi untuk beragama, potensi inetelektual yang menjadi dasar pola pikit kreatif, dan potensi untuk hidup bermasyarakat (naluri social), serta potensi nafsu (baik dan buruk) yang sifatnya menggerakan. ${ }^{18}$

Menurut persepsi penulis, paling tidak uraian di atas menekankan beberapa poin penting yang dapat dipahami terkait persoalan manusia memiliki fitrah/potensi. Pertama, menjelaskan bahwa fitrah/potensi pada substansinya dapat dimaknai sebagai suatu pembawaan, kesanggunpan atau kemampuan yang sejatinya telah dimiliki oleh setiap manusia. Kedua, mendeskripsikan bahwa dalam proses perkembangan fitrah/potensi yang ada dalam diri manusia, dapat dipengaruhi oleh lingkungan dan pendidikan. Ketiga, Penjabaran fitrah dengan kata al-insan dan la-basyar secara analogi mengungkapkan bahwa fitrah/potensi yang dimiliki manusia pada hakikatnya memenuhi dimensi ruhiyah dan jasaddiyah.

\section{Manusia Dapat Dididik dan Harus Mendidik}

Kedudukan manusia dalam proses pendidikan senantiasa diperbincangkan dalam perspekstif akademik, mengingat manusia adalah aktor utama selaku subjek dan objek pendidikan. Salah satu pokok persoalan yang selalu didiskusikan tentang manusia dalam pelaksanaan pendidikan adalah eksistensi manusia yang dapat dididik dan harus mendidik. Dalam al-Qur'an manusia digeneralkan dengan kosa kata al-insan berasal dari kata anasa yang arinya melihat, dan banyak dijelaskan dalam al-Qur'an, seperti firman Allah swt pada QS Thaha/20:10.

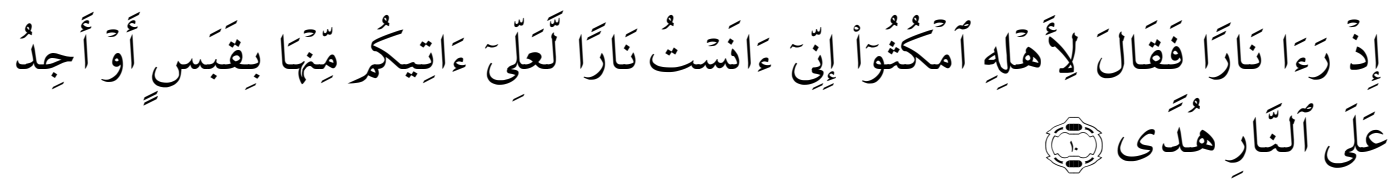

Terjemahnya: Ketika dia (Musa) melihat api, lalu berkatalah dia kepada keluarganya: "Tinggallah kamu (di sini), Sesungguhnya Aku melihat api, Mudah-mudahan Aku dapat membawa sedikit nyala api kepadamu atau Aku akan mendapat petunjuk di tempat api itu". ${ }^{19}$

\footnotetext{
${ }^{17}$ Lihat Nasir A. Baki, Filsafat Pendidikan Islam ...,66.

${ }^{18}$ Lihat Nasir A. Baki, Filsafat Pendidikan Islam..., 71.

${ }^{19}$ Departemen Agma RI, al-Qur'an dan Terjemahannya...,311.
} 
Kata anasa juga menyatakan manusia dapat menerima pelajaran dari Tuhannya tentang apa yang tidak diketahuinya, terdapat dalam QS al-'Alaq/96: 1-5, sebagai berikut:

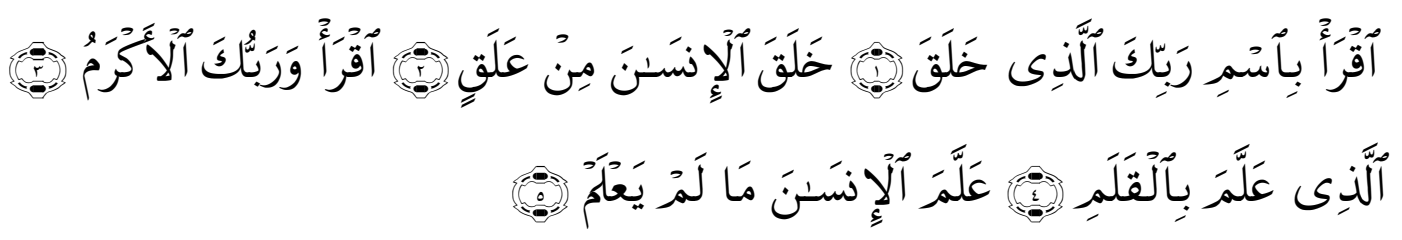

Terjemahnya: Bacalah dengan (menyebut) nama Tuhanmu yang Menciptakan, Dia telah menciptakan manusia dari segumpal darah. Bacalah, dan Tuhanmulah yang Maha pemurah, Yang mengajar (manusia) dengan pena. Dia mengajar kepada manusia apa yang tidak diketahuinya. ${ }^{20}$

Selain itu, ungkapan senada tentang manusia yang dapat menerima pelajaran dari Tuhan terkait al-bayan, yakni tentang perkataan yang fasih dan jelas termuat dalam QS al-Ahzab/33:72. Selanjutnya al-Qur'an menghubungkan kata la-insan dengan an-nas. Kata ini digunakan untuk menyatakan adanya kelompok orang atau masyarakat yang mempunyai berbagai kegiatan untuk mengembangkan kehidupannya. Seperti kegiatan manusia dalam bidang peternakan (QS al-Qasas/28:23, bidang perubahan sosial (QS al-Baqarah/2:164), bidang kepemimpinan (QS al-Baqarah/2:124). Kemudian kata al-insan juga dikaitkan dengan kemampuan manusia untuk menembus ruang angkasa (QS alRahman/55:33), serta dalam hubungan dengan tantangan terdapat dalam (QS alIsra/17:88. ${ }^{21}$ Dari beberapa ayat yang tersbutkan menurut interpretasi penulis, memberikan gambaran bahwa manusia dituntut untuk memiliki cakapan hidup/pengetahuan agar dapat mengembangkan diri dalam menjalani kehidupan bermasyarakat. Serangkaian informasi ayat-ayat al-Qur'an diatas menekankan bahwa kata insan dengan berbagai kata serumpun dengannya digunakan oleh alQur'an untuk menunjukan manusia sebagai makhluk yang berpkir dan berbudaya. Semua kegiatan yang dilakukan manusia, pada dasarnya dilakukan dengan kapasitas akal, dan aktualisasi dalam kehidupan konkret yakni mulai dari perencanaan, tindakan, dan sebab-akibatnya atau perolehan-perolehan yang ditimbulkan oleh kegiatan tersebut. ${ }^{22}$

Jika dinalisa secara seksama, semua kegiatan yang dilakukan manusia terwujud melalui proses belajar. Dengan proses belajar, manusia dapat memahami sesuatu, baik secara potensial maupun aktualnya, sehinga setiap manusia dapat meracang pekerjaan untuk mengolah sesuatu sehingga memberikan manfaat bagi

\footnotetext{
${ }^{20}$ Departemen Agma RI, al-Qur'an dan Terjemahannya ...,597.

${ }^{21}$ Lihat Nasir A. Baki, Filsafat Pendidikan Islam..., 66.

${ }^{22}$ Ibid., 68 .
} 
kepentingan hidupnya. ${ }^{23}$ Bahkan al-Qur'an menegaskan bahwa kata insane diartikan sebagai manusia yang dapat menerima pelajaran dari Tuhan tentang apa yang tidak diketahuinya. Dalam hubungannya Tuhan bertindak sebagai Guru Yang Maha Luas Ilmu-Nya, dan manusia menjadi murid-Nya yang terbatas pengetahuannya. ${ }^{24}$ Dengan demikian, dapat katakan bahwa manusia pada hakikatnya dapat dididik atau diberi pelajaran berdasarkan ukuran dan tingkat perkembangan pengetahuan yang ada dalam diri manusia.

Di samping kemampuan manusia untuk mengembangkan diri melalui proses belajar, manusia juga diwajibkan untuk mengajar atau mendidik orang lain, mengingat manasi telah diberikan fitrah sebgai pendidikan atau pengajar. Kemampuan mengajar dapat diaktulaisasikan sesuai dengan kondisi keterdidikan masing-masing orang. Di lingkugan pedesaan misalnya, harus sesuai taraf pedidikannya seperti; orang tua sebagai anggota inti dalam keluarga haru melaksanakan pengajaran secara lisan, baik dalam bentuk cerita, nasihat, larangan,, keteladanan (uswatun hasanah), dan sebagainya. ${ }^{25}$

Manusia memerlukan pendidikan, dikarenakan pendidikan mempunyai fungsi dan peranan penting untuk mengembangkan fitrah yang dimiliki manusia hanya dengan pendidikan, konsekuensi inilah yang menyebabkan adanya kewajiban manusia lain agar untuk mendidik orang lain. Kawajiban manusia untuk mendidik atau menjadi mengajar orang lain ditegaskan dalam hadis Nabi Muhammad swa sebagaimana dikutip Moh. Rifa'i, merujuk matan hadis yang dirwayat Albaikaqi "aku di utus untuk menjadi pengajar". ${ }^{26}$ Dengan demikian, dapat katakan bahwa mendidik atau memberikan pengajaran kepada sesama manusia adalah suatu kaharusan, dan menjadi tanggung jawab secara teologis. Secara umum uraian tentang persoalan manusia dapat dididik dan harus mendidik di atas, menurut hemat penulis terdapat dua hal yang dapat dipahami. Pertama, memberikan gambaran bahwa manusia secara fitrah membutuhkan pendidikan, yang artinya dapat dididik dan diberi pengajaran. Kedua, menekankan bahwa manusia memiliki tanggung jawab moral untuk mendidik manusia lainnya.

\section{Penutup}

Berangkat dari beberapa uraian sebelumnya, kaitanya dengan pembahasan tentang fungsi pendidikan Islam dalam hidup dan kehidupan manusia, maka dapat disimpulkan antara lain: 1) Manusia memiliki fitrah/potensi pada substansinya menekankan tentang kesanggupan, kemampuan atau pembawaan yang melekat

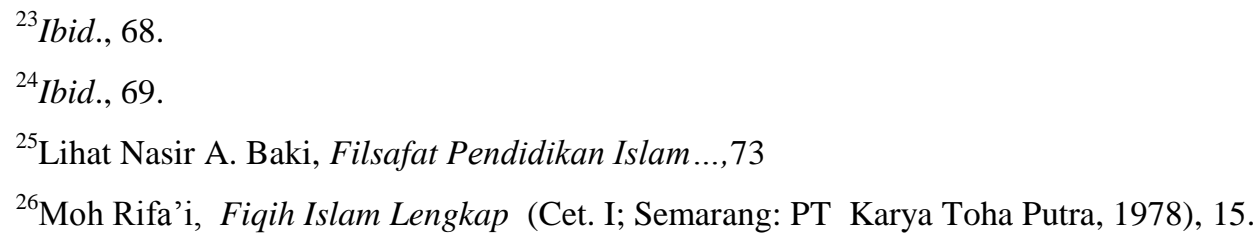


pada diri manusia. Ditinjau dalam konteks pendidikan Islam, pengejewantahan fitrah/potensi yang ada dalam diri manusia disimboliskan ke dalam makna kata alinsan dan al-basyar. 2) Manusia dapat dididik dan harus mendidik cenderung menekankan tentang eksistensi manusia secara fitrah memerlukan pendidikan atau dengan kata lain manusia dapat diberikan pelajaran. Di sisi lain, manusia juga dituntut untuk mendidik manusia lainnya. Dididik dan mendidik merupakan proses pembentukan fitrah manusia sehingga memiliki kecakapan hidup yang bermanfaat bagi kehidupan bermasyarakat.

\section{DAFTAR PUSTAKA}

Arifin, Muzayyin. Filsafat Pendidikan Islam. Cet. IV; Jakarta: PT Bumi Aksara, 2008.

Arifin. Ilmu Pendidikan Islam. Cet. V; Jakarta: PT Bumi Aksara, 2011.

Assegaf, Abd. Rachman. Filsafat Pendidikan Islam. Cet. II; Jakarta: PT Rajagrafindo persada, 2011.

Badaruddin, Kemas. Filsafat Pendidikan Islam . Cet. II; Yogyakarta: Pustaka Pelajar, 2009.

Baki, A. Nasir. Filsafat Pendidikan Islam. Cet. I; Makassar: Alauddin University Press, 2013.

Departemen Agma RI. al-Qur'an dan Terjemahannya . Jakata: PT Sygma Examedia Arkanleema, 2009.

Departemen Pendidikan Nasional, Kamus Besar Bahasa Indonesia, Edisi IV. Cet. I; Jakarta: Gramedia Pustaka Utama, 2008.

Hasbullah. Dasar-Dasar Pendidikan . Cet. X; Jakarta: PT Rajgrafindo Persada, 2012.

Khon, Abdul Majid. Hadis Tarbawi Hadis-Hadis Pendidikan . Cet. I; Jakarta: Kencana Prenada Media Group, 2012.

Partanto, A. Pius. Kamus Ilmiah Populer . Cet. I; Surabaya: Arkola, 2001.

Rifa'i, Moh. Fiqih Islam Lengkap . Cet. I; Semarang: PT Karya Toha Putra, 1978.

Sugiyono. Metode Penelitian Pendidikan:Pendekatan Kuantitatif, Kualitatif, dan $R \& D$. Cet. XIV; Bandung, 2012.

Tafsir, Ahmad. Ilmu Pendidikan Dalam Perspekstif Islam. Cet. IX; Jakarta: Remaja Rosdakarya, 2010. 